\title{
The Mediterranean is becoming saltier
}

\author{
M. Borghini ${ }^{1}$, H. Bryden ${ }^{1,2}$, K. Schroeder ${ }^{3}$, S. Sparnocchia ${ }^{4}$, and A. Vetrano ${ }^{1}$ \\ ${ }^{1}$ Istituto di Scienze Marine - ISMAR, Consiglio Nazionale delle Ricerche (CNR), Forte Santa Teresa, 19032 Lerici (SP), Italy \\ ${ }^{2}$ National Oceanography Centre Southampton, University of Southampton, Empress Dock, Southampton SO14 3ZH, UK \\ ${ }^{3}$ Istituto di Scienze Marine - ISMAR, Consiglio Nazionale delle Ricerche (CNR), Arsenale - Tesa 104, Castello 2737/F, \\ 30122 Venice, Italy \\ ${ }^{4}$ Istituto di Scienze Marine - ISMAR, Consiglio Nazionale delle Ricerche (CNR), Viale Romolo Gessi 2, 34123 Trieste, Italy
}

Correspondence to: H. Bryden (h.bryden@noc.soton.ac.uk)

Received: 29 January 2014 - Published in Ocean Sci. Discuss.: 26 February 2014

Revised: 3 June 2014 - Accepted: 13 June 2014 - Published: 7 August 2014

\begin{abstract}
The deep waters of the western Mediterranean Sea have become saltier and warmer for at least the past 40 years at rates of about 0.015 and $0.04{ }^{\circ} \mathrm{C}$ per decade. Here we show that two processes contribute to these increases in temperature and salinity. On interannual timescales, deep water formation events in severe winters transmit increasingly salty intermediate waters into the deep water. The second process is a steady downward flux of heat and salt associated with salt finger mixing down through the halocline-thermocline that connects the Levantine Intermediate Water with the deep water. We illustrate these two processes with observations from repeat surveys of the western Mediterranean basin we have made over the past 10 years.
\end{abstract}

\section{Introduction}

The Mediterranean Sea is an evaporative basin with an estimated freshwater (evaporation - precipitation - river runoff $=$ net evaporation) loss of 50 to $100 \mathrm{~cm} \mathrm{year}^{-1}$ (Bethoux, 1979; Bryden and Kinder, 1991). The Mediterranean also loses heat to the atmosphere at about 4 to $7 \mathrm{~W} \mathrm{~m}^{-2}$ (Bunker et al., 1982). Thus the Mediterranean is a concentration basin that loses buoyancy due to both freshwater loss and heat loss. For steady-state Mediterranean salinity and temperature distributions, the inflow-outflow through the Strait of Gibraltar balances these freshwater and heat losses: warmer, fresher Atlantic inflow and colder, saltier Mediterranean outflow transport freshwater and heat into the Mediterranean Sea to balance the buoyancy losses (Bryden et al., 1994; Macdonald et al., 1994).
Nof (1979) first suggested that the steady-state water balance for the Mediterranean was measurably disrupted by the damming of the Nile River during the 1960s. Considering the damming of the Nile River inflow, Nof estimated a change to the overall freshwater budget of the Mediterranean Sea equal to an increase in net evaporation of $13 \mathrm{~cm}_{\text {year }}{ }^{-1}$. Using hydraulic control theory to model the changes in Gibraltar exchange associated with a $10 \%$ increase in net evaporation, Rohling and Bryden (1992) estimated that the salinity of the outflowing Mediterranean water would need to increase by 0.13 to bring the Mediterranean back into steady state.

Lacombe et al. (1985) carefully examined historical hydrographic data in the western Mediterranean and could find no evidence for changes to the salinity and temperature of the deep water from 1910 to 1970 . They did report some fascinating variability in deep water properties measured by CTD in 1973 and again in 1981 and we will show that changes to the historical deep water properties were already underway when they made these profiles. Since 1985, many authors have estimated the rates of increase in salinity and temperature in the deep western Mediterranean: some argue that they are effects associated with global warming, heating and evaporating the surface layers around the deep convection region in the Gulf of Lion (e.g. Béthoux and Gentili, 1999; Krahmann and Schott, 1998); some argue for increasing temperature and salinity in the Atlantic water inflow through the Strait of Gibraltar (e.g. Millot, 2007); some to changes in air-sea fluxes related to variability in the North Atlantic Oscillation (e.g. Rixen et al., 2005); and some (e.g. Rohling and Bryden, 1992) attribute the increases to hydraulic control 
requirements associated with the changing water budget due to the damming of rivers, particularly the Nile River

A careful model study by Skliris and Lascaratos (2004) compared Mediterranean circulations with and without Nile River discharge. They showed that removing the Nile River discharge caused the salinity of the Mediterranean to increase by about 0.04 over a timescale of 40 years. In the model, the increase in salinity occurred first in the surface waters of the eastern Mediterranean which resulted in an increase in salinity of the newly formed Levantine Intermediate Water (LIW). The circulation of the saltier LIW then led to saltier deep water formation in the eastern Mediterranean and when the LIW made its way into the western Mediterranean it eventually preconditioned the upper $1000 \mathrm{~m}$ in the Gulf of Lion to be salty enough to form deep water in moderately severe wintertime storms. Such processes do seem to occur. New, saltier Aegean Sea deep water was indeed formed in the eastern Mediterranean during 1988-1992 in what is commonly referred to as the Eastern Mediterranean transient (Roether et al., 1996). This saltier LIW is observed to transit the Sicily Channel (Gasparini et al., 2005) and to precondition the waters in the Gulf of Lion (Grignon et al., 2010) for large deep water formation events that result in saltier Western Mediterranean Deep Water (WMDW) (Schroeder et al., 2010). Gačić et al. (2013) argued that oscillations in the salinity of LIW entering the western Mediterranean through the Sicily Channel are caused by bimodal oscillations in the circulation of the eastern Mediterranean with a timescale of order 10 years and that the higher salinity LIW directly results in deep water formation events in the Gulf of Lion about 15 years later causing jumps in deep salinity and temperature of the western Mediterranean. Here we emphasize the long-term increases in salinity and temperature of the deep western Mediterranean associated with salt finger processes as well as the jumps in salinity and temperature associated with deep water formation events.

\section{Data}

To quantify long-term changes in the deep water properties, we use selected high quality historical stations at location $\mathrm{A}$ in the western Mediterranean near the entrance to the Alboran Sea (Table 1, Fig. 1). To quantify more recent changes in deep water properties over the last decade, we use stations occupied by R/V Urania as part of CNR (Consiglio Nazionale delle Ricerche) repeat surveys of the western Mediterranean Sea in 2004, 2005, 2006, 2008, 2010 and 2013 (stations 1 to 17 in Fig. 1) and a station in 2011 occupied by R/V Meteor during a west-east transect of the Mediterranean (Tanhua et al., 2013). We also use the monthly time series of DYFAMED (Dynamique des Flux Atmosphériques en Méditerranée) CTD profiles in the northwestern Mediterranean to examine continuous time series of changing deep water properties from 1995 to 2008.
Table 1. Depth-average salinity, potential temperature and potential density referenced to 2000 dbar below 200 dbar for historical stations in the western Mediterranean near the eastern entrance to the Alboran Sea. Potential density referenced to 2000 dbar is defined as density -1000 in units of $\mathrm{kg} \mathrm{m}^{-3}$. The 1961 station is Atlantis station 6010 in Miller et al. (1970). The 1975 station is Chain station 79 in Bryden et al. (1978). The 1995 station is Meteor station 2 from Roether et al. (1996). The 2004 and 2008 stations are Urania stations made as part of CNR repeat surveys of the western Mediterranean Sea (Schroeder et al., 2010). CTD station data have a precision in salinity of 0.003 and in temperature of $0.001{ }^{\circ} \mathrm{C}$, while the older Atlantis discrete bottle data have a precision in salinity of 0.01 and in temperature of $0.003{ }^{\circ} \mathrm{C}$. Differences in expedition methodologies and instrumentation lead to possible biases in salinity and temperature of 0.01 and $0.005^{\circ} \mathrm{C}$ between expeditions.

\begin{tabular}{rrrr}
\hline Year & Salinity & $\begin{array}{r}\text { Potential } \\
\text { temperature }\end{array}$ & $\begin{array}{r}\text { Potential } \\
\text { density }\end{array}$ \\
\hline 1961 & 38.406 & 12.766 & 37.736 \\
1975 & 38.431 & 12.822 & 37.742 \\
1995 & 38.452 & 12.879 & 37.744 \\
2004 & 38.477 & 12.966 & 37.741 \\
2008 & 38.478 & 12.954 & 37.745 \\
\hline
\end{tabular}

CTD station data have a precision in salinity of 0.003 and in temperature of $0.001{ }^{\circ} \mathrm{C}$, while the older discrete bottle data have a precision in salinity of 0.01 and in temperature of $0.003^{\circ} \mathrm{C}$. Differences in expedition methodologies and instrumentation lead to possible biases in salinity and temperature of 0.01 and $0.005^{\circ} \mathrm{C}$ between expeditions. Thus, in estimating changes over time by taking differences between expeditions, there are uncertainties in salinity and temperature difference of 0.014 and $0.007^{\circ} \mathrm{C}$, but these uncertainties are independent of the time interval over which they are taken. For this reason we try to take differences over longer time intervals so the uncertainties in decadal differences are 0.014 per decade and $0.007^{\circ} \mathrm{C}$ per decade whereas uncertainties in yearly differences would amount to 0.14 per decade and $0.07^{\circ} \mathrm{C}$ per decade.

\section{Magnitude of the salinity and temperature increases}

Over the past 47 years the Mediterranean Sea has been becoming saltier and warmer. We chose a location, A, in the western Mediterranean near the entrance to the Alboran Sea (Fig. 1) to compare temperature and salinity profiles in five stations spanning 47 years from 1961 to 2008 (Fig. 2). We specifically chose this location to represent Mediterranean waters near the end of their circuit of the basin and about to exit the Mediterranean. Both the hightemperature, high-salinity core of LIW and the cold relatively fresh WMDW have become notably warmer and saltier since 1961 (Fig. 2). The increases in LIW core temperature and salinity are about twice as large as the changes in the 


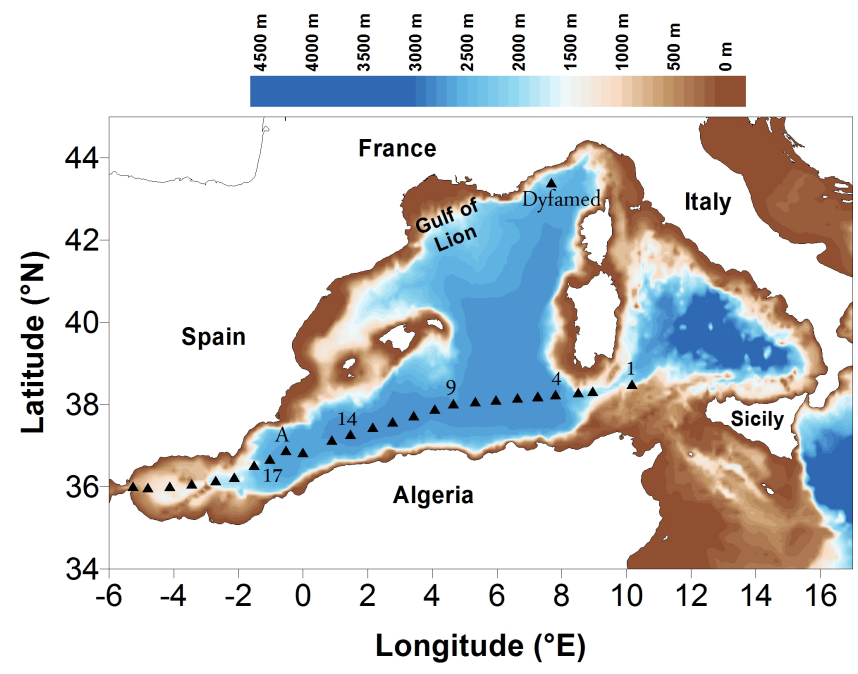

Figure 1. Map of hydrographic stations in the western Mediterranean Sea that are used here to examine the processes leading to long-term changes in deep Mediterranean temperature and salinity. Here we focus on long-term (1961-2008) changes in temperature and salinity of the Mediterranean waters at location A at the eastern entrance to the Alboran Sea and on recent (2004-2013) changes at station 9. Stations 4 to 17 were used by Bryden et al. (2014) to estimate downward heat, salt and density fluxes into the deep water. Also indicated is the DYFAMED station with monthly time series temperature and salinity profiles extending back to 1991 .

deepest waters. Averaging the salinity and potential temperature below $200 \mathrm{~m}$ depth (to minimize seasonal effects in the upper waters) shows that the salinity and temperature have increased by $0.07 \pm 0.014(0.015 \pm 0.003$ per decade $)$ and $0.19^{\circ} \mathrm{C} \pm 0.007^{\circ} \mathrm{C}\left(0.040^{\circ} \mathrm{C} \pm 0.001{ }^{\circ} \mathrm{C}\right.$ per decade $)$ respectively since 1961 (Table 1). If such changes were due to changes in the evaporation-precipitation-runoff and air-sea heat exchange, they amount to an increase in evaporation or decrease in precipitation or in runoff of $12 \mathrm{~cm} \mathrm{year}^{-1}$ (which is similar to Nof's estimate for the effects of damming the Nile River) and to a decrease in air-sea heat loss by the ocean of $1.6 \mathrm{~W} \mathrm{~m}^{-2}$ over 50 years.

These Mediterranean changes are larger and penetrate more deeply than the patterns of global ocean warming and freshening/salinification recently summarized by Rhein et al. (2013). For example the global ocean heat content increase is estimated to be equivalent to a heating of $0.55 \mathrm{~W} \mathrm{~m}^{-2}$ and the temperature increases are concentrated in the upper $700 \mathrm{~m}$. For the global ocean there are bands of increased salinity and decreased salinity - in general there is increased salinity in zones of net evaporation and decreased salinity in zones of net precipitation and the change in salinity is concentrated again above $700 \mathrm{~m}$ depth. For example at $40^{\circ} \mathrm{N}$ in the Atlantic Ocean, the upper ocean salinity has increased at a rate of 0.02 per decade, comparable to the change in Mediterranean salinity, but the higher salinity signature is absent below $500 \mathrm{~m}$ depth (Fig. 3.5 in Rhein et al., 2013).
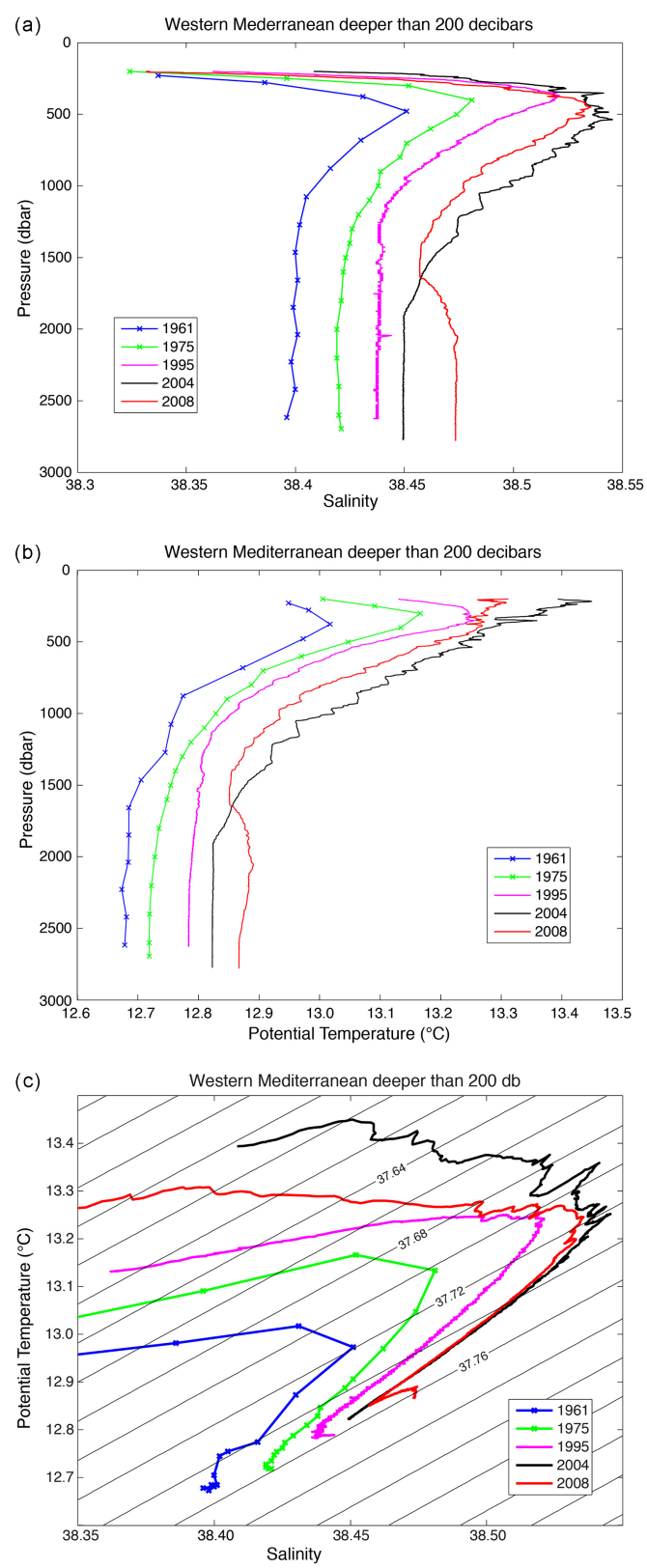

Figure 2. Profiles of (a) salinity and (b) potential temperature versus pressure for historical stations at location A at the eastern entrance to the Alboran Sea. (c) Potential temperature-salinity diagrams for the historical stations with contours of potential density referenced to $2000 \mathrm{dbar}$. Levantine Intermediate Water (LIW) is evident as a salinity maximum at about 400 dbar for each station. Western Mediterranean Deep Water (WMDW) is the deep water below 2200 dbar at each station. The halocline-thermocline between the depth of the LIW at 400 dbar and the top of the deep water below $1800 \mathrm{dbar}$ has a stratification where warm, saltier waters overlie colder fresher waters and this stratification is conducive to salt finger mixing processes. Depth-averaged salinity, potential temperature and potential density referenced to 2000 dbar below 200 dbar are given for each station in Table 1. 
Thus the Mediterranean changes are about a factor of 3 larger than observed in the open ocean and they penetrate all the way through the water column to the bottom. Here we try to understand the processes that enable the warming and salinification to penetrate to the bottom.

Much has been made of the long-term salinification of the Mediterranean Sea with an emphasis on the role of deep water formation events occurring sporadically in severe winters that mix the salty LIW down into the deep water (Schroeder et al., 2010). In fact, one can see that process in Fig. 2 by examining the differences between the 2004 and 2008 profiles: the intervening deep water formation event of 2005 transmitted the high-salinity, high-temperature LIW evident in 2004 profiles down into the deep water making the 2008 deep waters appreciably warmer and saltier than the 2004 deep waters.

In addition to deep water formation events, Bryden et al. (2014) argued that double-diffusive salt finger processes transfer salinity and temperature downward into the WMDW. The halocline-thermocline connecting the core of LIW at about 400 dbar and the WMDW below 1900 dbar depth consists of warmer, saltier waters lying above colder, fresher deep waters (Fig. 2) and such stratification is conducive to salt finger processes that transfer heat, salt and density downward. Here we compare the downward fluxes of heat and salt through the halocline-thermocline into the deep water with the downward fluxes associated with deep water formation events to assess their respective roles in increasing the temperature and salinity of the deep western Mediterranean.

We examine observations from a set of repeated surveys of the deep western Mediterranean Sea over the past decade to compare the effects of sporadic deep water formation events with the effects of steady downward fluxes of salt and heat into the deep waters on causing the long-term increases in salinity and temperature of the WMDW. We focus initially on the observations at station 9 (Fig. 1) in the open ocean region of the southern western Mediterranean to describe the evolution of deep water properties. We have sampled station 9 in 2004, 2005, 2006, 2008, 2010 and 2013 on board R/V Urania and a station at this location was sampled by R/V Meteor in 2011 (Tanhua et al., 2013). Vertical profiles of salinity and potential temperature and a potential temperature-salinity diagram for these stations show the evolution of deep water properties over the past decade (Fig. 3).

In 2004 we observe the deep water to be nearly uniform vertically below $1900 \mathrm{dbar}$ with a potential temperature of $12.82^{\circ} \mathrm{C}$ and salinity of 38.45 . By 2005 , the deep water layer 1900-2700 dbar appears to have become slightly warmer and saltier and below 2700 dbar a thin bottom layer of warmer and saltier water appears. This bottom layer is the new warmer, saltier deep water formed during the extreme winter of 2005 in the northwestern Mediterranean (Schroeder et al., 2008; Smith et al., 2008) that is just arriving at station 9. This major deep water formation event ultimately injected a $600 \mathrm{~m}$ thick layer of new deep water into the
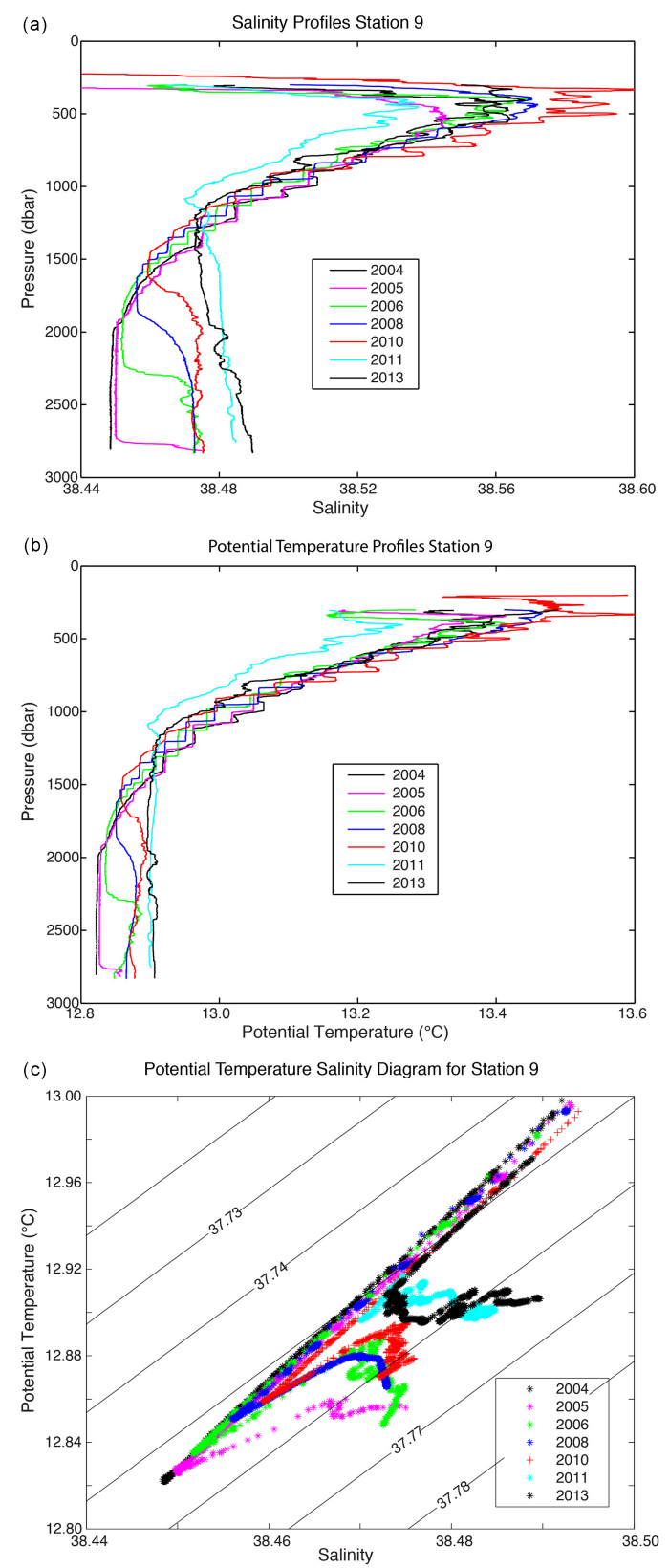

Figure 3. Profiles of (a) salinity and (b) potential temperature versus pressure for the repeat occupations at station 9; (c) potential temperature-salinity diagrams for these recent stations below $1000 \mathrm{dbar}$ with contours of potential density referenced to 2000 dbar. Levantine Intermediate Water (LIW) is evident as a salinity maximum at about $400 \mathrm{dbar}$ for each station. Western Mediterranean Deep Water (WMDW) is the deep water below 1800 dbar at each station. The halocline-thermocline between the depth of the LIW at $400 \mathrm{dbar}$ and the top of the deep water below $1500 \mathrm{dbar}$ has a stratification where warm, saltier waters overlie colder fresher waters and this stratification is conducive to salt finger mixing processes. Depth-averaged salinity, potential temperature and potential density referenced to 2000 dbar over 1900-2750 dbar and 15001900 dbar are given for each station in Table 2. 
(a)

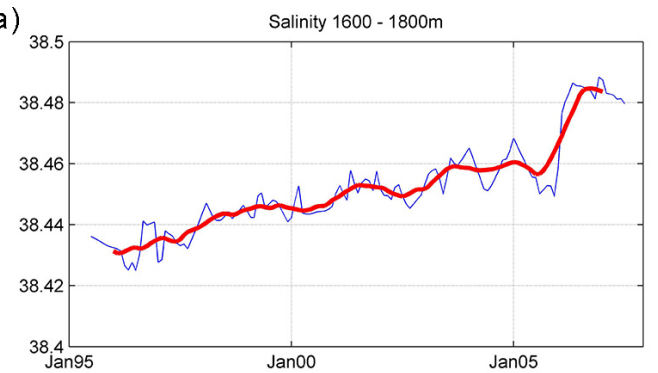

(b)

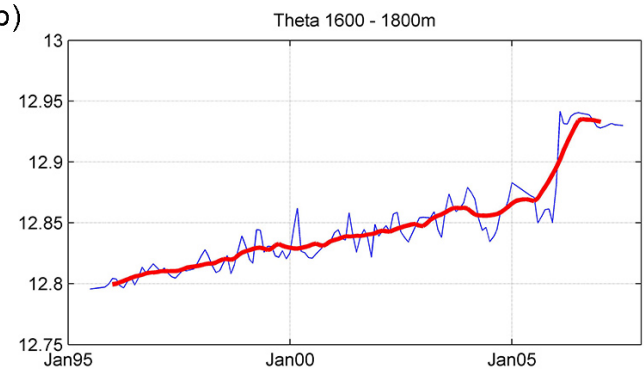

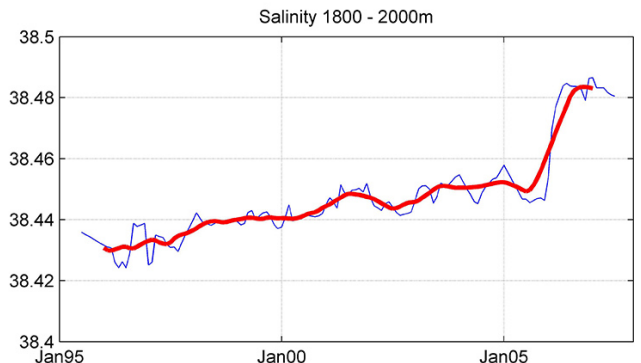

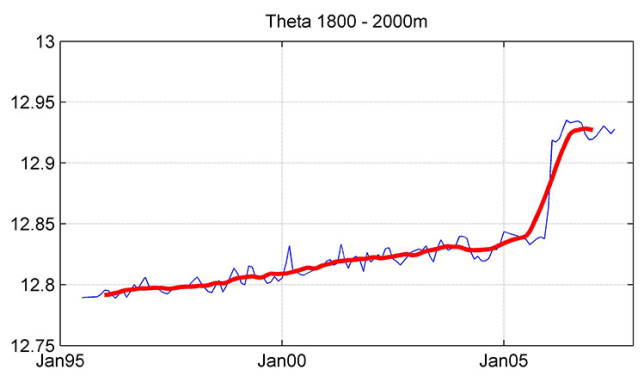

Figure 4. Time series average (a) salinity and (b) potential temperature in the layers 1600-1800 m and 1800-2000 m at the DYFAMED station in the Ligurian Sea. Monthly values are plotted in blue while running mean 13-month average values are plotted in red.

deep western Mediterranean Sea that was 0.024 saltier and $0.042{ }^{\circ} \mathrm{C}$ warmer than the previous bottom waters (Fig. 3a and b, Schroeder et al., 2010) that we see at station 9 by 2006.

Over the succeeding 4-year period from 2006 to 2010, the layer between the bottom of the halocline-thermocline and the top of the deep water becomes appreciably saltier and warmer. Using repeats of stations 4 to 17 (Fig. 1) from 2006, 2008 and 2010, Bryden et al. (2014) showed that the increases in salinity and temperature in the region between the bottom of the halocline-thermocline and the top of the deep water were consistent for all stations and they estimated the downward fluxes of heat and salt through the halocline-thermocline into the deep water associated with salt finger processes to be $5.4 \times 10^{-8} \mathrm{psu} \mathrm{m} \mathrm{s}^{-1}$ and $12.4 \times 10^{-8}{ }^{\circ} \mathrm{C} \mathrm{m} \mathrm{s}^{-1}$. Such fluxes would make a $1000 \mathrm{~m}$ column of deep water 0.017 saltier and $0.39^{\circ} \mathrm{C}$ warmer over the course of a decade.

By 2010, the deep waters at station 9 are nearly uniform vertically below $1800 \mathrm{dbar}$ and have potential temperature of $12.88^{\circ} \mathrm{C}$ and salinity of 38.474 , nearly $0.06^{\circ} \mathrm{C}$ warmer and 0.025 saltier than the old deep waters of 2004. By 2011 there appears to have been some new deep water formation raising the deep water temperature to $12.90^{\circ} \mathrm{C}$ and salinity to 38.482 and by 2013 there has been additional deep water formation (Durrieu de Madron et al., 2013) raising the deepest salinity to 38.49 but with little change in potential temperature. From 2010 to 2013, the layer between the bottom of the haloclinethermocline and the top of the deep water continues to fill in with higher temperature and salinity. Over the decade of our recent observations, deep water properties below $1900 \mathrm{dbar}$ have increased in temperature by $0.080^{\circ} \mathrm{C} \pm 0.007^{\circ} \mathrm{C}$ and increased in salinity by $0.035 \pm 0.014$ (Table 2); these are twice the rates of increase found from 1961 to 2008. And in the vertical depth range from 1500 to 1900 dbar above the direct influence of new deep water formation where salt finger fluxes are operating the waters have become warmer and saltier by $0.042^{\circ} \mathrm{C} \pm 0.007^{\circ} \mathrm{C}$ and $0.016 \pm 0.014$ over a decade (Table 2). These rates are the same size as the rates of increase from 1961 to 2008.

Thus, two processes are contributing to the increases in salinity and temperature of the deep water. First, salt finger processes transport salt and heat steadily downward through the halocline-thermocline at estimated rates of $5.4 \times 10^{-8}$ psu m s${ }^{-1}$ and $12.4 \times 10^{-8}{ }^{\circ} \mathrm{C} \mathrm{m} \mathrm{s}^{-1}$, respectively (Bryden et al., 2014). These amount to downward salt and heat fluxes over a year of $1.7 \mathrm{psu} \mathrm{m}$ and $3.9^{\circ} \mathrm{Cm}$. Secondly, sporadic deep water formation events in the northwest Mediterranean inject new warmer, saltier denser deep water that then spreads beneath the older deep waters. The major deep water formation event in 2005 resulted in downward fluxes of $14.4 \mathrm{psu} \mathrm{m}(600 \mathrm{~m} \times 0.024 \mathrm{psu})$ and $25.2^{\circ} \mathrm{C} \mathrm{m}$ $\left(600 \mathrm{~m} \times 0.042{ }^{\circ} \mathrm{C}\right)$, that is 6 to 8 times larger than the yearly downward flux associated with salt finger mixing. In contrast, the deep water formation event of 2012 documented by Durrieu de Madron et al. (2013) that created a large volume of new deep water had smaller downward fluxes of 2 psu m $(200 \mathrm{~m} \times 0.010 \mathrm{psu})$ and $2{ }^{\circ} \mathrm{Cm}\left(200 \mathrm{~m} \times 0.01^{\circ} \mathrm{C}\right)$ because the salinity excess in the new deep water was not as large as in 2005 and there was nearly no potential temperature signature. Concentrating on the major 2005 event, we estimate 
Table 2. Depth-average salinity, potential temperature and potential density referenced to 2000 dbar at station 9 in the western Mediterranean over the past decade: deep water 1900-2750 dbar and above the direct influence off deep water formation 1500-1900 dbar. Potential density referenced to $2000 \mathrm{dbar}$ is defined as density - 1000 in units of $\mathrm{kg} \mathrm{m}^{-3}$. Stations in 2004, 2005, 2006, 2008, 2010, 2013 were occupied by RV Urania as part of CNR repeat surveys of the western Mediterranean Sea; the station in 2011 was occupied by R/V Meteor during a west-east transect of the Mediterranean (Tanhua et al., 2013). CTD station data have a precision in salinity of 0.003 and in temperature of $0.001{ }^{\circ} \mathrm{C}$. Differences in expedition methodologies and instrumentation lead to possible biases in salinity and temperature of 0.01 and $0.005^{\circ} \mathrm{C}$ between expeditions.

\begin{tabular}{|c|c|c|c|c|c|c|}
\hline \multirow[b]{2}{*}{ Year } & \multicolumn{3}{|c|}{ Average 1900-2750 dbar } & \multicolumn{3}{|c|}{ Average $1500-1900 \mathrm{dbar}$} \\
\hline & Salinity & $\begin{array}{r}\text { Potential } \\
\text { temperature }\end{array}$ & $\begin{array}{r}\text { Potential } \\
\text { density }\end{array}$ & Salinity & $\begin{array}{r}\text { Potential } \\
\text { temperature }\end{array}$ & $\begin{array}{r}\text { Potential } \\
\text { density }\end{array}$ \\
\hline 2004 & 38.449 & 12.824 & 37.755 & 38.459 & 12.856 & 37.755 \\
\hline 2005 & 38.450 & 12.828 & 37.755 & 38.461 & 12.860 & 37.755 \\
\hline 2006 & 38.463 & 12.857 & 37.758 & 38.457 & 12.850 & 37.755 \\
\hline 2008 & 38.470 & 12.873 & 37.759 & 38.458 & 12.854 & 37.754 \\
\hline 2010 & 38.474 & 12.881 & 37.760 & 38.464 & 12.873 & 37.754 \\
\hline 2011 & 38.482 & 12.900 & 37.762 & 38.480 & 12.906 & 37.758 \\
\hline 2013 & 38.484 & 12.904 & 37.762 & 38.475 & 12.898 & 37.757 \\
\hline
\end{tabular}

that for a major deep water formation event occurring every 7 years the episodic warming and salinification of the deep water is the same size as the steady warming and salinification associated with downward fluxes of heat and salt through the halocline-thermocline.

We can see the effects of these two processes in the monthly time series of CTD profiles of salinity and temperature at the DYFAMED site in the Ligurian Sea from 1995 to 2008 (Fig. 4). There the deep water temperature and salinity in the northwest Mediterranean increased nearly linearly from 1995 to 2005 before the large deep water formation event in 2005 occurred (Schroeder et al., 2010). We estimate an increase in $1800-2000 \mathrm{~m}$ temperature of $0.05^{\circ} \mathrm{C} \pm 0.007$ and an increase in salinity of $0.027 \pm 0.014$ over the decade from 1995 to 2005 . Hence even in a decade where there is little evidence for deep water formation in the western Mediterranean, deep water salinity and temperature increase at a rate comparable to the long-term trends seen at location A (Table 1). These steady changes over 10 years are slightly smaller than the jumps we see in the DYFAMED observations in layer temperature $\left(0.08^{\circ} \mathrm{C} \pm 0.007^{\circ} \mathrm{C}\right)$ and salinity $(0.04 \pm 0.014)$ from 2005 to 2007 associated with the major 2005 deep water formation event.

\section{Discussion}

The two processes that increase the salinity of the deep water, salt finger mixing and deep water formation events, have different signatures. Salt fingers transport heat, salt and density downwards making the deep waters warmer, saltier and denser. We expect the salt finger processes to be steady in the sense that the stratification with warmer saltier LIW above colder fresher WMDW enables salt finger processes to proceed year-round. On the other hand, deep water formation events are sporadic, occurring in late winter and only in severe winters. New deep water initially has a salinity close to the column average salinity in the formation region of the northwest Mediterranean because the wintertime formation events are not of long enough duration to appreciably change the salinity over a water column $2500 \mathrm{~m}$ thick (Smith et al., 2008). At the onset of deep convection, the temperature of the new deep water must be that temperature that combines with the water-column average salinity to equal or just exceed the density of the existing deep water (Leaman and Schott, 1991). As severe winter heat loss (mostly due to evaporation) continues, the new deep water can become colder and slightly saltier and denser, but mostly colder. Thus, deep water formation leads to saltier and warmer deep water only if the column-average salinity in the formation region is increasing.

The presence of high-salinity LIW is critical to both processes. It sets the deep stratification where warmer saltier intermediate waters lie above colder fresher deep waters that is conducive to salt finger processes. Also, high-salinity LIW preconditions the water column in the deep water formation region so that severe winter heat losses can mix down through the LIW and generate new deep water (Schroeder et al., 2010). The source of LIW is in the eastern Mediterranean, its core salinity in the western Mediterranean has increased by about 0.10 since the 1960 s (Fig. 2a), and this increase in LIW salinity is ultimately the cause of the saltier deep water in the western Mediterranean.

It is notable that the density of the Mediterranean intermediate and deep waters in the western Mediterranean at station A has not changed much over the past 47 years (Fig. 2c). The core of LIW has had a potential density referenced to the surface of about sigma- $0=29.07$ (and sigma- $2=$ potential density referenced to $2000 \mathrm{dbar}=37.72$, Fig. $2 \mathrm{c}$ ) since the 1960s. Deep water potential density has also remained fairly 
constant at about sigma- $2=37.75$ (sigma- $0=29.11$ ) since the 1960 s, with perhaps a small increase to 37.764 in the 2005 deep water formation and maybe to 37.766 in the 2012 deep water formation event (Durrieu de Madron et al., 2013) as observed in the properties at station 9 in Fig. 3c. Vertical mechanical mixing of new bottom waters with slightly less dense waters above gradually erodes the initially higher density of the deep waters so that over time there has been effectively no increase in deep water density. Temperature and salinity have increased but the density has stayed nearly constant as the temperature and salinity changes compensate in density. In terms of processes, the constancy of deep density is an argument for deep water formation events as the dominant source for increases in deep salinity because salt finger processes should lead to an increase in deep density as well as to increases in salinity and temperature. However, the increase in deep density associated with salt finger mixing is very small, amounting to only $0.004 \mathrm{~kg} \mathrm{~m}^{-3}$ per decade according to Bryden et al. (2014) so that over 50 years the deep potential density would have increased by only $0.02 \mathrm{~kg} \mathrm{~m}^{-3}$ and that change would be beyond the observational uncertainty in comparing surveys across 50 years.

That the density of Mediterranean water has not changed by very much over 50 years is contrary to Rohling and Bryden's (1992) arguments for the increasing salinity of the Mediterranean. They argued that the salinity of the Mediterranean is set by hydraulic control processes determining the maximum exchange for the flows between the Atlantic and Mediterranean through the Strait of Gibraltar. Their hypothesis was that increasing net evaporation (due to reduced river run-off) must ultimately lead to an increase in Mediterranean salinity and density that allows a stronger exchange flow through the Strait to balance the higher net evaporation. Rohling and Bryden (1992) were actually arguing that an increase in density of the Mediterranean water by about $0.2 \mathrm{~kg} \mathrm{~m}^{-3}$ was necessary to enable a stronger exchange flow to balance the increased net evaporation. No such sizeable increase in density has in fact been observed over the past 50 years since the damming of the Nile River.

Prior to 1969 , the salinity of the deep water in the western Mediterranean was apparently in steady state (Lacombe et al., 1985) allowing oceanographers to assume steady-state processes. For the Mediterranean Sea we traditionally use steady state heat and salt conservation statements for the Mediterranean basin with inflow and outflow through the Strait of Gibraltar at Atlantic and Mediterranean water salinities to derive the Knudsen relationships that quantify the size of the inflow and outflow as a function of the net evaporation over the Mediterranean. Bryden and Kinder (1991) added steady hydraulic theory to the heat and salt conservation statements to show how the salinity of the Mediterranean could be determined as a function of the net evaporation over the Mediterranean.
But the Mediterranean Sea is clearly not in a steady state: temperature and salinity have been rising steadily since the 1960s; river run-off has been reduced as rivers are dammed and used for irrigation; and models suggest that evaporation is increasing due to the warming climate. Adjusting our steady-state views of the Mediterranean requires careful consideration of the time-dependent heat and freshwater budgets. For example, how can we modify the Knudsen relations for the Gibraltar exchange for an increasing net evaporation and an increasing salinity of the Mediterranean?

Will the Mediterranean ever reach a steady state in response to global warming and the changing water balance associated with increased evaporation and reduced river runoff? How long can the salinity of the Mediterranean continue to increase? What value will it achieve? Answering these questions represents a challenge for the Mediterranean modelling community and validating the model predictions will require continuing observations of the deep Mediterranean Sea.

Acknowledgements. We thank CNR for continuing support for sustained observations in the Mediterranean Sea by providing the $\mathrm{R} / \mathrm{V}$ Urania, and in particular the Operational Planning Office (UPO) for help with logistics. The captain and officers of $\mathrm{R} / \mathrm{V}$ Urania ensured the safe and efficient scientific operations on all expeditions. H. Bryden thanks the Leverhulme Trust for supporting his involvement in this Mediterranean climate change research. The authors acknowledge the Observatoire Océanologique de Villefranche sur Mer Service d'Observation and, in particular, Laurent Coppola for providing the DYFAMED monthly CTD time series. We thank CNR-IAMC (Oristano, Italy) and in particular Alberto Ribotti for providing additional profiles that were used for comparison and quality control.

Edited by: T. Tanhua

\section{References}

Béthoux, J. P.: Budgets of the Mediterranean Sea, their dependence on the local climate and on characteristics of the Atlantic waters, Oceanologica Acta, 2, 157-163, 1979.

Béthoux, J. P. and Gentili, B.: Functioning of the Mediterranean Sea: Past and present changes related to freshwater input and climate changes, J. Mar. Syst., 20, 33-47, 1999.

Bryden, H. L. and Kinder, T. H.: Steady two-layer exchange through the Strait of Gibraltar, Deep-Sea Res., 38 (Supplement 1), S445S463, 1991.

Bryden, H. L., Millard, R. C., and Porter, D. L.: CTD observations in the western Mediterranean Sea during Cruise 118, Leg 2 of R/V Chain, February, 1975. Woods Hole Oceanographic Institution Technical Report WHOI-78-26, 38 pp., 1978.

Bryden, H. L., Candela, J., and Kinder, T. H.: Exchange through the Strait of Gibraltar, Prog. Oceanogr., 33, 201-248, 1994.

Bryden, H., Schroeder, K., Borghini, M., Vetrano, A., and Sparnocchia, S.: Mixing in the deep waters of the western Mediterranean, in: The Mediterranean Sea: Temporal Variability and Spatial Pat- 
terns, edited by: Borzelli, G. L. E., Gačić, M., Lionello, P., and Malanotte-Rizzoli, P., Geophysical Monograph 202, American Geophysical Union, 51-58, 2014.

Bunker, A. F., Charnock, H., and Goldsmith, R. A.: A note on the heat balance of the Mediterranean and Red Seas, J. Mar. Res., 40 (Supplement), 73-84, 1982.

Durrieu de Madron, X., Houpert, L., Puig, P., Sanchez-Vidal, A., Testor, P., Bosse, A., Estournel, C., Somot, S., Bourrin, F., Bouin, M. N., Beauverger, M., Beguery, L., Calafat, A., Canals, M., Cassou, C., Coppola, L., Dausse, D., D’Ortenzio, F., Font, J., Heussner, S., Kunesch, S., Lefevre, D., Le Goff, H., Martín, J., Mortier, L., Palanques, A., and Raimbault, P.: Interaction of dense shelf water cascading and open-sea convection in the northwestern Mediterranean during winter 2012, Geophys. Res. Lett. 40, 1379-1385, doi:10.1002/grl.50331, 2013.

Gačić, M., Schroeder, K., Civitarese, G., Cosoli, S., Vetrano, A., and Eusebi Borzelli, G. L.: Salinity in the Sicily Channel corroborates the role of the Adriatic-Ionian Bimodal Oscillating System (BiOS) in shaping the decadal variability of the Mediterranean overturning circulation, Ocean Sci., 9, 83-90, doi:10.5194/os-983-2013, 2013.

Gasparini, G. P., Ortona, A., Budillon, G., Astraldi, M., and Sansone, E.: The effect of the Eastern Mediterranean Transient on the hydrographic characteristics in the Strait of Sicily and in the Tyrrhenian Sea, Deep-Sea Res. Pt. I, 52, 915-935, 2005.

Grignon, L., Smeed, D. A., Bryden, H. L., and Schroeder, K.: Importance of the variability of hydrographic preconditioning for deep convection in the Gulf of Lion, NW Mediterranean, Ocean Sci., 6, 573-586, doi:10.5194/os-6-573-2010, 2010.

Krahmann, G. and Schott, F.: Long term increases in Western Mediterranean salinities and temperatures: anthropogenic and climatic sources, Geophys. Res. Lett. 25, 4209-4212, 1998.

Lacombe, H., Tchernia, P., and Gamberoni, L.: Variable bottom water in the Western Mediterranean basin, Prog. Oceanogr., 14, 319-338, 1985.

Leaman, K. D. and Schott, F. A.: Hydrographic structure of the convection regime in the Gulf of Lions: Winter 1987, J. Phys. Oceanogr., 21, 575-598, 1991.

Macdonald, A. M., Candela, J., and Bryden, H. L.: An estimate of the net heat transport through the Strait of Gibraltar, in: Seasonal and Interannual Variability of the Western Mediterranean Sea, edited by: LaViolette, P., Coastal and Estuarine Studies, 46, 1332, 1994.

Miller, A. R., Tchernia, P., Charnock, H., and McGill, D. A.: Mediterranean Sea Atlas, Woods Hole Oceanographic Institution, 190 pp., 1970.
Millot, C.: Interannual salinification of the Mediterranean inflow, Geophys. Res. Lett., 34, L21609, doi:10.1029/2007GL031179, 2007.

Nof, D.: On man-induced variations in the circulation of the Mediterranean Sea, Tellus, 31, 558-564, 1979.

Rhein, M., Rintoul, S. R., Aoki, S., Campos, E., Chambers, D., Feely, R. A., Gulev, S., Johnson, G. C., Josey, S. A., Kostianoy, A., Mauritzen, C., Roemmich, D., Talley, L. D., and Wang, F.: Observations: Ocean. Chapter 3 in: Climate Change 2013: The Physical Science Basis. Contribution of Working Group I to the Fifth Assessment Report of the Intergovernmental Panel on Climate Change, edited by: Stocker, T. F., Qin, D., Plattner, G.-K., Tignor, M., Allen, S. K., Boschung, J., Nauels, A., Xia, Y., Bex, V., and Midgley, P. M., Cambridge University Press, Cambridge, 2013.

Rixen, M., Beckers, J.-M., Levitus, S., Antonov, J., Boyer, T., Maillard, C., Fichaut, M., Balopoulos, E., Iona, S., Dooley, H., Garcia, M.-J., Manca, B., Giorgetti, A., Manzella, G., Mikhailov, N., Pinardi, N., and Zavatarelli, M.: The western Mediterranean deep water: A proxy for climate change, Geophys. Res. Lett. 32, L12608, doi:10.1029/2005GL022702, 2005.

Roether, W., Manca, B. B., Klein, B., Bregant, D., Georgopoulos, D., Beitzel, V., Kovačević, V., and Luchetta, A.: Recent Changes in Eastern Mediterranean Deep Waters, Science, 271, 333-335, 1996.

Rohling, E. J. and Bryden, H. L.: Man-induced salinity and temperature increases in western Mediterranean deep water. J. Geophys. Res., 97, 11191-11198, 1992.

Schroeder, K., Ribotti, A., Borghini, M., Sorgente, R., Perilli, A., and Gasparini, G. P.: An extensive western Mediterranean deep water renewal between 2004 and 2006, Geophys. Res. Lett., 35, L18605, doi:10.1029/2008GL035146, 2008.

Schroeder K., Josey, S. A., Herrmann, M., Grignon, L., Gasparini, G. P., and Bryden, H. L.: Abrupt warming and salting of the Western Mediterranean Deep Water after 2005: Atmospheric forcings and lateral advection, J. Geophys. Res., 115, C08029, doi:10.1029/2009JC005749, 2010.

Skliris, N. and Lascaratos, A.: Impacts of the Nile River damming on the thermohaline circulation and water mass characteristics of the Mediterranean Sea, J. Mar. Syst. 52, 121-143, 2004.

Smith, R. O., Bryden, H. L., and Stansfield, K.: Observations of new western Mediterranean deep water formation using Argo floats 2004-2006, Ocean Sci., 4, 133-149, doi:10.5194/os-4-133-2008, 2008.

Tanhua, T., Hainbucher, D., Schroeder, K., Cardin, V., Álvarez, M., and Civitarese, G.: The Mediterranean Sea system: a review and an introduction to the special issue, Ocean Sci., 9, 789-803, doi:10.5194/os-9-789-2013, 2013. 